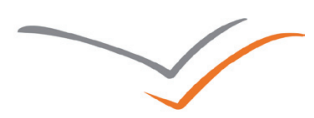

STUDIA HISTORIAE OECONOMICAE

UAM Vol. $31 \quad$ Poznań 2013

\title{
VERSITA
}

Maurycy Kustra (Adam Mickiewicz University, Poznań)

\section{LAY-OUT AND SPATIAL DEVELOPMENT OF TOWNS FROM GREAT POLAND IN THE 13TH CENTURY - PRELIMINARY RESEARCH}

This paper deals with the problem of shaping landscape. The examples of towns of Great Poland from the $13^{\text {th }}$ century were implemented and used. Their layout was not accidental. Towns were created with a substantial dose of accuracy. A market square was precisely laid out; roads were turned straight to the nearby towns, and plots were created for townsmen. It tended to be the final product of human thought and idea. The comparison of towns' sizes shows that the same measures and similar schemes were used. In a medieval town each and every aspect was carefully planned and wellthought-out, but sometimes it was modified due to the terrain. Subsequent generations interpreted landscape on their own and occasionally changed the layout of a town. The contemporary appearance of towns is a product of thought materialisation in the living space. That is why the landscape of towns can be analysed and read.

Keywords: urban history, spatial development, urban development, late Middle Ages.

doi:10.2478/sho-2013-0002

Research on the medieval cities and towns of Great Poland has singled out, especially when it comes to the level of development on the scale of the country in the middle of the 20th century ${ }^{1}$. Unfortunately, the realisation of this research problem has been abandoned, which results in its current state in comparison with other parts of Poland ${ }^{2}$. As a matter of fact,

${ }^{1}$ See H. Múnch, Geneza rozplanowania miast wielkopolskich XIII i XIV wieku, Kraków 1946 and later studies on bigger cities, particularly Poznań. Studies pertaining to modern locations of Great Polands' towns and cities from the 16th to the 18th century was carried out by: Z. Kulejewska-Topolska, Nowe lokacje miejskie w Wielkopolsce od XVI do końca XVIII wieku. Studium historyczno-prawne, Poznań 1964 and G. Wróblewska, Rozplanowanie nowożytnych miast w Wielkopolsce od XVI do końca XVIII wieku, Warszawa-Poznań 1977.

2 Valuable works are devoted to Lower Silesia and Lesser Poland, see: R. Eysymontt, Kod genetyczny miasta. Średniowieczne miasta lokacyjne Dolnego Ślaska na tle urbanistyki europejskiej, Wrocław 2009; B. Krasnowolski, Lokacyjne układy urbanistyczne na obszarze ziemi kra- 
a lot of archaeological excavations are conducted, which have a significant influence on the aforementioned issues. However, the outcomes of those studies are not published. Thus, they do not exist in the scholarly literature. Furthermore, the present state of research on the biggest centers of the region is highly advanced (especially for Poznan, but also Gniezno, Kościan and Kalisz). Nevertheless, those regions do not represent all towns and cities of Great Poland, because they constitute only small percentage of big centers and do not give an outlook concerning the entire towns and cities arrangement.

In this paper the potential threats lurking for a town of the oppidum category during the Medieval Times will be considered. My MA thesis and articles encompassed the medieval settlement of Pobiedziska and its vicinity $^{3}$, that is why this town will be used as an example. Due to the lack of archaeological and historical sources, some aspects will be treated roughly.

\section{THE DIVISION OF CITIES AND TOWNS. CIVITAS AND OPPIDUM}

First and foremost, towns and cities' categories in the Medieval Times in Poland are worth introducing.

The distinction in terminology exists also in sources. Therefore, the following division can be encountered in the written texts:

- civitas - city;

- oppidum - town. This term embraces in its meaning medium and small city centers.

Polish towns and cities in 1500 (around 700 centers) can be divided into 4 tax groups:

kowskiej w XIII i XIV w. Część I. Miasta Ziemi Krakowskiej, chronologia procesów osadniczych i typologia układów urbanistycznych, Kraków 2004; B. Krasnowolski, Lokacyjne układy urbanistyczne na obszarze ziemi krakowskiej w XIII i XIV w. Część II. Katalog lokacyjnych układów urbanistycznych, Kraków 2004.

${ }^{3}$ M. Kustra, Osadnictwo średniowieczne okolic Pobiedzisk [Medieval settlement in the vicinity of Pobiedziska], Poznań 2010 [MA thesis supervised by prof. dr hab. Hanna Kóčka-Krenz in Institute of Prehistory, University of Adam Mickiewicz, Poznań, defended in June 2010]. Research outcomes concerning Pobiedziska are being published - M. Kustra, Pobiedziska wraz z okolica w średniowieczu i u progu nowożytności, Poznań-PobiedziskaGniezno 2013.

${ }^{4}$ H. Samsonowicz, Życie miasta średniowiecznego, Poznań 2001. 
- civitates primi ordinis - 6 cities from Poland; from Great Poland Poznań numbered about 8 thousand of inhabitants;

- civitates - from 80 to 90 centers in the Polish Kingdom, 1-4 thousand of inhabitants, for instance Gniezno, Kalisz and Śrem.

- oppida with trade fairs and fairs - about 230 centers, up to around 1 thousand of inhabitants;

- oppida without trade fairs and fairs - over 360 centers, 100-400 of inhabitants.

Around 85 percent of cities were small centers (the oppidum category, 3 and 4 tax categories). They displayed agricultural character and were inhabited by around 300 people. However, works regarding bourgeoisie tackle with bigger centers (civitates). A lot of studies concern mostly big cities, passing over smaller centers - towns (oppida).

In 1458 during the seym in Środa a number of foot soldiers from a given city going on the Thirteen Years War was established ${ }^{5}$. Among the distinguished 139 units on the list, are worth mentioning those, which were to send the biggest amount of foot soldiers. Those were:

- Poznań - 60;

- Kościan - 40;

- Kalisz and Pyzdry - per 30;

- Gniezno, Koźmin, Śrem, Środa, Wschowa, Słupca - per 20;

- Buk, Gostyń, Koło, Konin, Międzyrzecz, Oborniki, Pobiedziska, Rogoźno, Stawiszyn, Września, Żnin - per 15.

On top of that, it is also worth pointing out that these towns and cities were mainly situated in the Central Great Poland around the major settlement units.

\section{THE BEGINNINGS OF TOWNS}

Towns were created in a specific socio-cultural situation characterised by the demographic growth. A huge increase of the archaeological sites was observed dated from the turn of the E and $F$ phases (from the half of the 13th century; Graph 1$)^{6}$. This situation can be linked with other data

${ }^{5}$ Kodex dyplomatyczny Wielkiej Polski, zawierający bulle papieżów, nadania książą, przywileje miast, klasztorów i wsi, wraz z innemi, podobnéj treści dyplomatami, tyczacemi się historyi téj prowincyi od roku 1136. do roku 1597, E. Raczyński (wyd.), Poznań 1840, p. 181.

${ }^{6} \mathrm{I}$ conducted detailed research in this matter about Pobiedziska and its vicinity (The Great Poland). This town is situated in the middle, between Poznan and Gniezno; M. Kustra, Osadnictwo średniowieczne okolic Pobiedzisk, Poznań 2010. 
Graph 1. The number of medieval sites from Pobiedziska commune according to the medieval phases (till the late medieval and modern times)

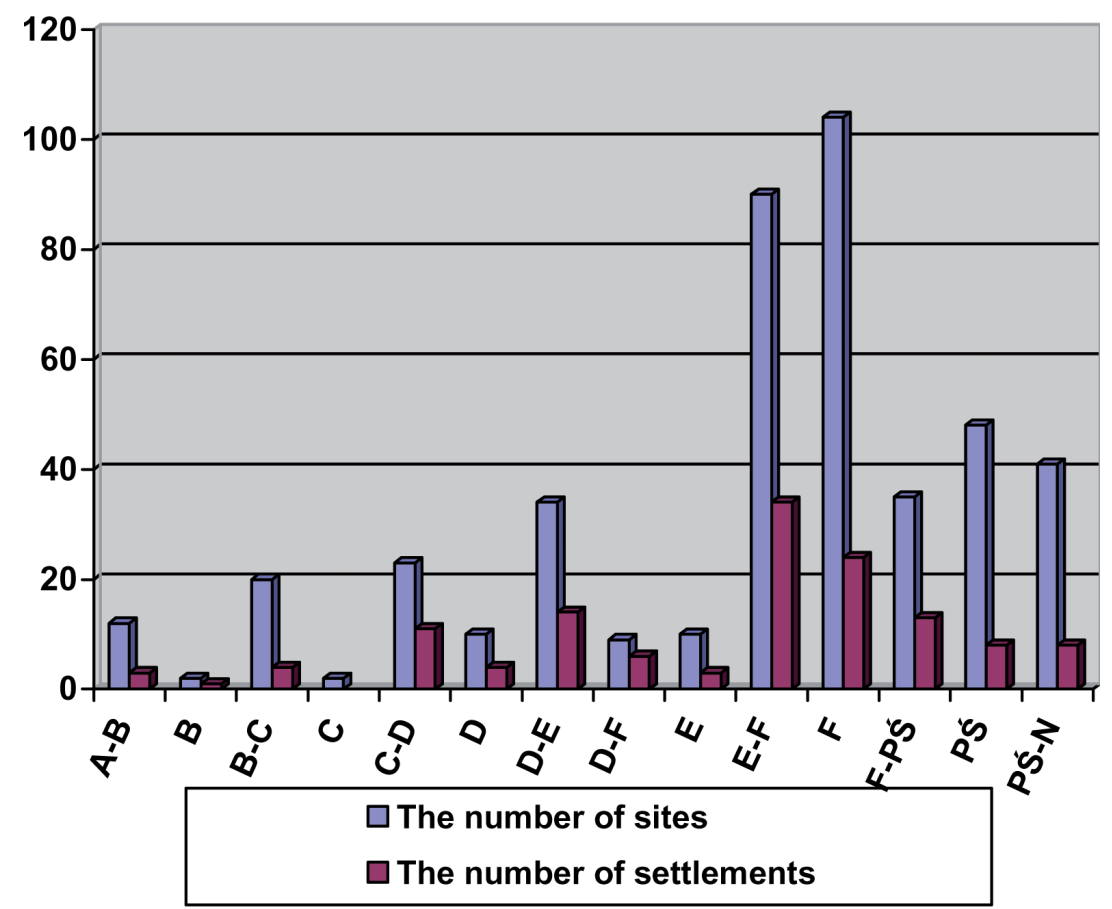

for instance from the palinological diagrams. A considerable increase of the fields along with the significant decrease of forests was spotted.

Towns locations in the 13th century Great Poland are connected with the rule of the local Piast dynasty ${ }^{7}$. During the life of Wladyslaw Odonic, Przemysl I and Boleslaus Pious around 28 towns were located. However, about 50 towns were located till the year 1314. Around 139 towns and cities existed in the middle of the 15th century.

The place for future town was precisely chosen. The choice of the final placement consisted of a few important aspects ${ }^{8}$ :

7 The beginning of the town's location in Great Poland till 1314, see: Z. Górczak, Najstarsze lokacje miejskie w Wielkopolsce (do 1314 r.), Poznań 2002.

${ }^{8}$ Such conclusion is drawn after the analysis of the location of the oldest Great Poland towns, located till 1279 (the end of the reign of Boleslaw Pobożny). These eldest Great Poland towns are as follows: Gniezno, Powidz, Międzyrzecz, Kostrzyn, Śródka, Poznań, Śrem, Pyzdry, Krzywiń, Kcynia, Ruda, Pobiedziska, Kłecko, Bolesławiec, Zduny, Kalisz, Lądek, Żnin, Gostyń, Wronki and most probably Środa, Oborniki, Wschowa, Buk, Jarocin, Rogoźno, Święciechowa and also Stare Szamotuły. 
Figure 1. The 21 biggest towns and cities of Great Poland in the middle of the 15th c.

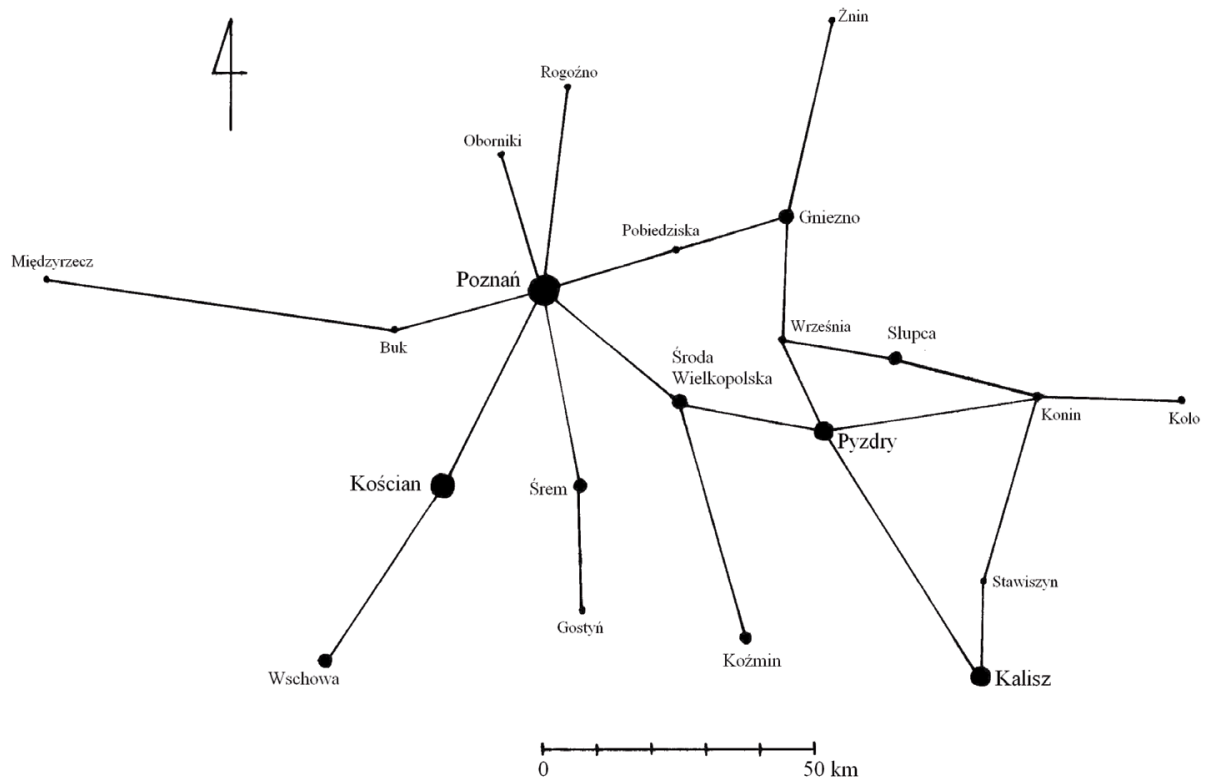

a) the vicinity of river or lake;

b) placement often on a small hill;

c) the distance between neighbouring towns or cities - cities were situated from one another about $50 \mathrm{~km}$ ( 2 days on foot or by cart, which equals 1 day by horse). Medium towns, however, were situated from each other around $25 \mathrm{~km}$ (1 day trip) ;

d) the vicinity of well-trodden trails and trade routes was important for the new place and for the future development of town.

In the Great Poland there were around 4-5 central sites of the region, namely Poznań, Gniezno, Pyzdry, Kalisz and Kościan. They constituted a net whose particular elements were situated from each other about 2 days trip. They created the central part of the region, its heart. The civitas category was predominant (about 8 ), which was located in the vicinity of major centers ${ }^{9}$. The most significant towns of Great Poland can be presented due to the list of soldiers sent by each town to the Thirteen Years War in the middle of the 15th century (1458) (Fig. 1). Big and important centers

9 The towns dubbed as civitas, for instance, see Liber beneficiorum archidiecezyi gnieźnieńskiej, t.1, Gniezno 1880 [Liber beneficiorum of the Gniezno Archibishop], KDW SN i MRPS. 
of the region are shown here as well as smaller sites included to medium towns (compared with those in the country or in Europe they were treaated as small towns). The aforementioned towns were located on the major routes and in the central part of Great Poland.

\section{SPATIAL RELATIONS BETWEEN TOWNS}

Due to the location of towns in certain distances ( 1 or 2 days trip ca $25-30 \mathrm{~km}$ and ca $50-60 \mathrm{~km}$ ) using the Christallers hexagonal method the placement of the towns can be explained ${ }^{10}$. The theory of the central site treats reality as a logical and coherent system, which comprises elements of different importance. This model helps creating an area, which elements constitute an arrangement and concentrate around the central site. Different criteria of the less important sites in haxagon are dependent on: optimisation of transport (the centers of the hexagon), the distance from the market (the corners of the hexagon), administartive issues (distant from the border of hexagon).

The range of the whole hexagon is dependent on the distance from the center to the border covered in a specific time.

The reconstruction of the most significant centers of Great Poland can be done using Christaller's hexagonal method, because it shows the aspirations to create the world in a regular manner and the need to travel in the most logical and efficient way.

The central sites in the middle of the 14th century comprise big towns, such as: Poznań-Gniezno-Pyzdry-Kalisz, and in the extended version also Kościan (Fig. 2). In the middle of big centers also smaller sites were needed. These were located 1 day trip from them (therefore, the role of Pobiedziska, Środa and Września of the upmost importance).

The comparison between the ideal and real distances (Fig. 3), shows that the distance is changeable. It was dependent on the natural and cultural conditions.

10 The application of the Christaller's hexagonal method can be found in: M. Kustra, Aplikacja metody sześcioboków Christallera do refleksji nad średniowieczną Wielkopolską w kontekście roli Pobiedzisk, Studia Lednickie, X/2010, s. 89-105; M. Kustra, Rekonstrukcja liczby ludności Pobiedzisk w przeszłości, Studia Lednickie, X/2010, s. 151-159; M. Kustra, Pobiedziska wraz z okolica w średniowieczu i u progu nowożytności, Poznań-Pobiedziska-Gniezno 2013. 
Figure 2. Christaller's hexagonal method used for main centers in Great Poland (the middle of the 13th c.

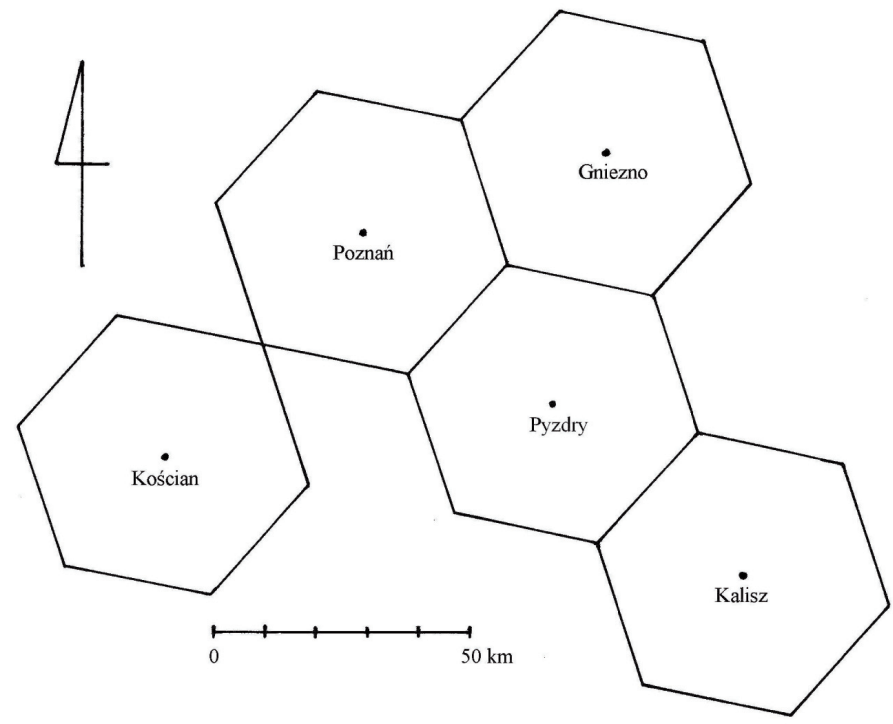

Figure 3. The realistic placement of settlements compared with the ideal hexagons

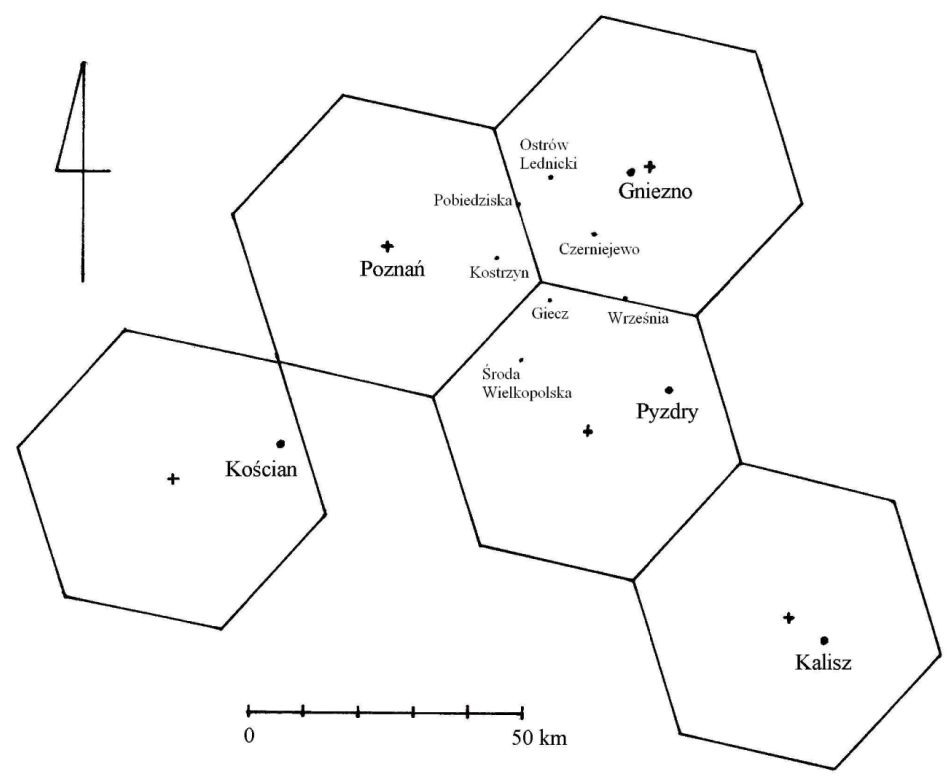




\section{TOWNS'S LAY OUT}

The next element, which is worth mentioning, is town's lay out. The most simple clasification was based on it and on shape of the market ${ }^{11}$. The Great Poland towns were divided into three categories:

a) square-shaped market - eg. Powidz, Międzyrzecz, Kostrzyn, Poznań, Pobiedziska, Kłecko, Zduny, Środa, Old Szamotuły;

b) rectangular-shaped market - eg. Gniezno, Śródka, Śrem, Pyzdry, Krzywiń, Kcynia, Lądek, Żnin, Gostyń;

c) quadrangular market and spindle-shaped road system - eg. Kalisz, Wronki, Wschowa.

Among the oldest towns the lay out schemes can be established ${ }^{12}$. Towns with square-shaped market were oval, which was 5-6 ropes wide, and had market $2 \times 2$ ropes. However, towns with rectangular-shaped market were oval, but bigger, $6-9 \times 3-6$ ropes and they had small market $1 \times 2$ or $1 \times 3$ ropes.

The range of the town and the market was laid out but also routes and plots were established. All these elements were connected with topography (eg. lakes, rivers or hills)but especially with road connections.

I would like to present an exemplary range of Great Poland town with square market place, which was established for Pobiedziska (Fig. 4). For the medieval times the following division into two phases can be shown ${ }^{13}$ :

- the first phase - the second half of the 13th century. During this stage the plots around the placed oval shaped town were settled. The town had a church of St. Michael Archangel. The basis when it comes to the placing of the town was a square (6 ropes on one side, which is about 282 meters), divided into smaller squares ( 2 ropes on one side, which amounts around 94 meters).

- the second phase - from the 15th to the 16th century, which has its roots in the 14th century. In this stage the town grew especially down the Poznan-Gniezno route. On a smaller scale down the way to Czerniejewo

\footnotetext{
11 See: map of lay out types, H. Múnch, Geneza rozplanowania miast wielkopolskich XIII i XIV wieku, Map 2, p. 102.

12 These are the preliminary results of my own studies over the 13th century towns of Great Poland. These works are conducted within the confines of my Ph.D dissertation under prof. dr hab. Hanny Kóčka-Krenz's guidance at the Institute of Prehistory of Adam Mickiewicz University in Poznań.

${ }^{13}$ M. Kustra, Osadnictwo średniowieczne okolic Pobiedzisk...; M. Kustra, Rekonstrukcja liczby ludności Pobiedzisk; M. Kustra, Pobiedziska wraz z okolica w średniowieczu...
} 
Figure 4. The range of different types of medieval pottery in Pobiedziska

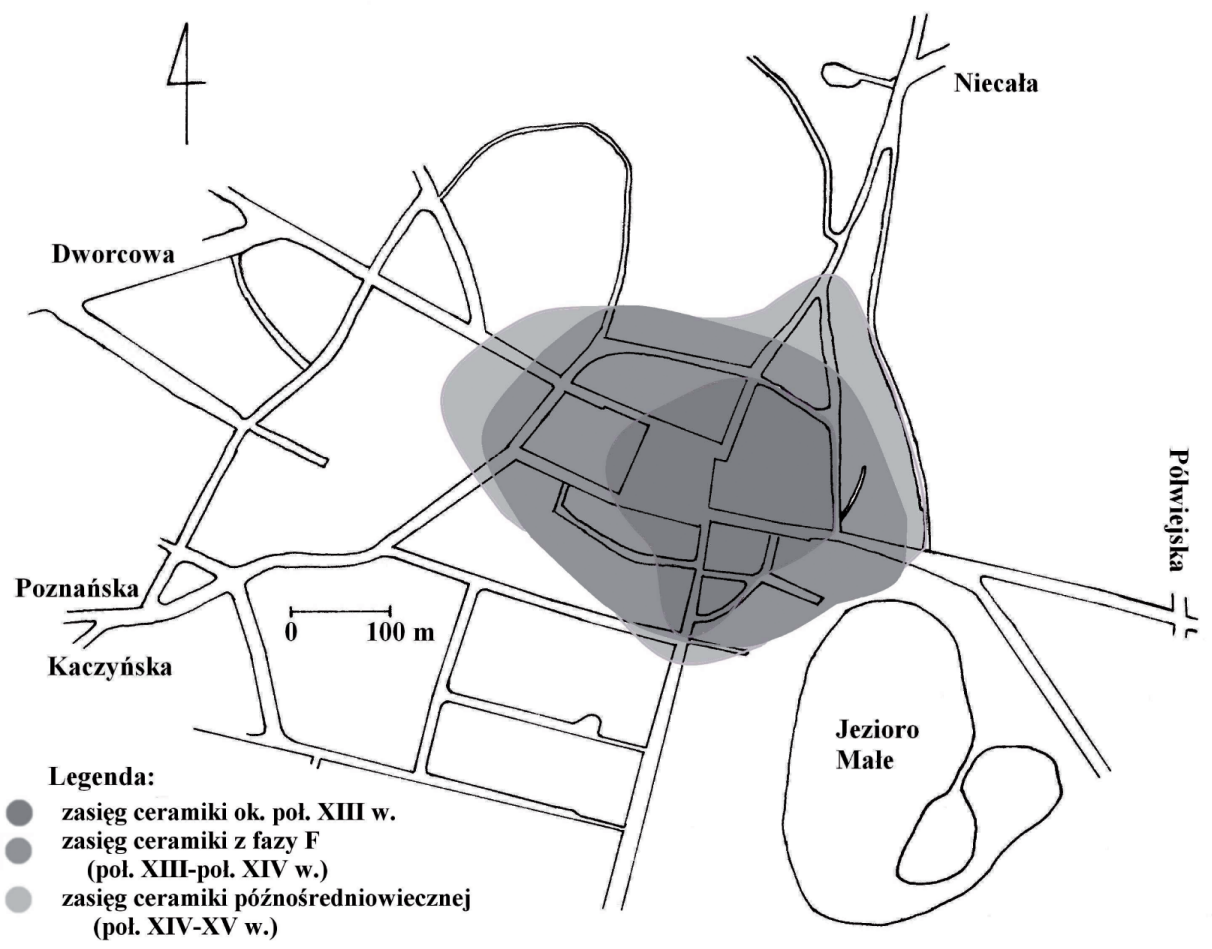

and Kostrzyn. An irregular shape was formed, which was a consequence of the lack of fortifications. They would delimit and fix the range of settlement. In town in the first half of the 15th century St. Spirit church and hospital were founded.

Poznan the biggest city in Great Poland from the very beginning was designed with grand splendour. It had a big, square market ( $3 \times 3$ ropes) which altogether reached $11 \times 11$ ropes $(10-11 \times 11-11,5 \text { rope })^{14}$. Poznan could be compared with only the biggest cities of Poland, because towns of Great Poland were much smaller and had smaller markets.

14 See studies devoted to the lay out of Poznań: M. Chorowska, Rozplanowanie średniowiecznego Poznania na tle miast śląskich, [in:] [in:] Z. Kurnatowska, T. Jurek (red.), Civitas Posnaniensis. Studia z dziejów średniowiecznego Poznania, Poznań 2005, s. 207-224; A. Kąsinowski, Rozplanowanie średniowiecznego Poznania na tle miast hanzeatyckich, [in:] Z. Kurnatowska, T. Jurek (red.), Civitas Posnaniensis. Studia z dziejów średniowiecznego Poznania, Poznań 2005, s. 225-242. 


\section{TOWNS WITH SQUARE-SHAPED MARKET PLACE - GREAT POLAND AND LOWER SILESIA}

The Lower Silesia is valuable when it comes to the comparison of phenomena connected with establishing the settlement centers. The reason for that is as follows - here the earliest new towns were established. That is why it is crucial to discover whether the origins of towns with a square market were caught on from this area. The analysis encompasses centers containing a market in the square shape, because it is more rare than the rectangular market. The comparison will be made between towns, which were located till 3/4 quarter of the 13th century, because these are the oldest centers. One should also take into consideration the shape of the established center, its lay out, the size of the market and the course of the trade routes.

On top of that this paper will also take into account the following towns:

a) from the Lower Silesia with a square shaped market or similar to a square: Lubań, Szprotawa, Trzebnica, Żmigród and on a smaller scale (with an uncertain location date; perhaps located later than the chronology of this paper grabs) Kożuchów, Milicz, Nowe Miasteczko, Polkowice, Prusice and Radków. On the other hand Wrocław with its market similar to square can be comapred with Poznań.

b) from Great Poland: Powidz, Międzyrzecz, Kostrzyn, Pobiedziska, Kłecko, Zduny, Środa Wielkopolska, Stare Szamotuły, Wronki and on a lesser scale Poznan (this city is layed out as a big civitas and should be compared with other big centers from other regions of the country).

Comparing all Lower Silesias' and Great Polands' towns one can draw conclusion that among the oldest centers in the latter region are more centers with a square shaped market. On the other hand, Lower Silesia has a small percentage of towns which are comparable with Great Poland's. A hypothesis emerges that towns with a square shaped market were characteristic to Great Poland and were established on the basis of a certain scheme (the analysis of their lay out from the 2nd half of the 13th century shows it very clearly).

\section{SPATIAL DE5VELOPMENT}

Thanks to the settlement research using especially archaeological excavations (which show the range of pottery from different phases of the 
Figure 5. Pobiedziska in the 2nd half of the 13th century - including market, church, main roads and size of town

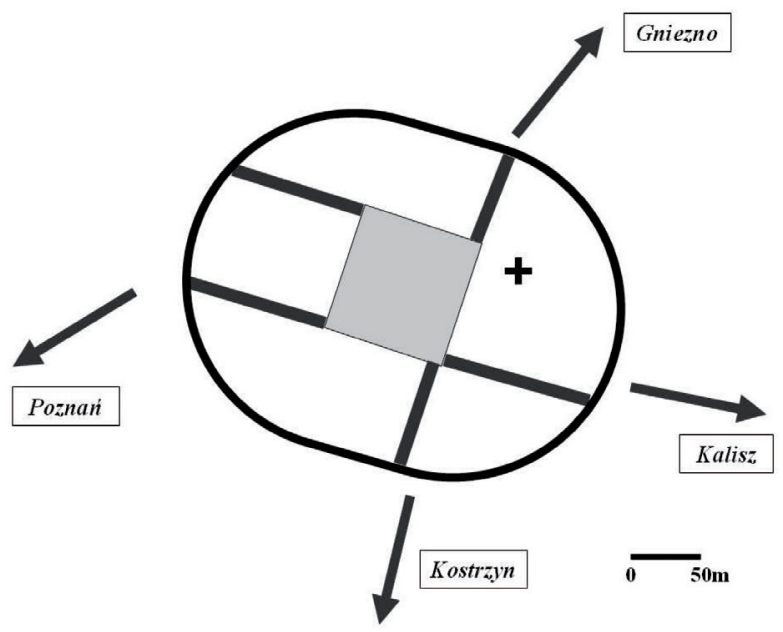

Middle Ages), it is possible to estimate the area which was used by men in various periods. Therefore, it is feasible to define spatial development - phases in different periods of time. At first it was limited to the square market and its nearest vicinity, but then it expanded (Fig. 4). Using different types of sources it is possible to estimate phases of town range (Fig. 5 and 6).Similar analyses are being carried out in other towns of Great Poland.

The usage of plots in the demographic reconstruction can create a model of the town population (Graph 2) ${ }^{15}$. For example in the first stage of its range (most probably in the second half of the 13th century) Pobiedziska was inhabited by 60 families, which amounted roughly 300-330 people. According to the reconstruction the developed second phase encompassed around 130-136 plots (the increase is about 70-76). They could have been inhabited by about $650-748$ people. It is without doubt, that no more than 1.000 inhabitants lived there.

The demographic explosion is observed from the 19th century, or at times from the end of the 18th century ${ }^{16}$. The growth of the number

${ }^{15}$ M. Kustra, Osadnictwo średniowieczne okolic Pobiedzisk...; M. Kustra, Rekonstrukcja liczby ludności Pobiedzisk.

${ }^{16}$ Such demographic reconstructions can be done with the help of estimating the number of plots in different chronological ranges - the exemplary usage of this method is applied to establish the number of inhabitants in Pobiedziska; M. Kustra, Osadnictwo średniowieczne okolic Pobiedzisk...; M. Kustra, Rekonstrukcja liczby ludności Pobiedzisk....; M. Kustra, Pobiedziska wraz z okolica w średniowieczu. 
Figure 6. Spatial development of Pobiedziska (2nd half of the 13th c. till the turn of the 18th and 19 th century)

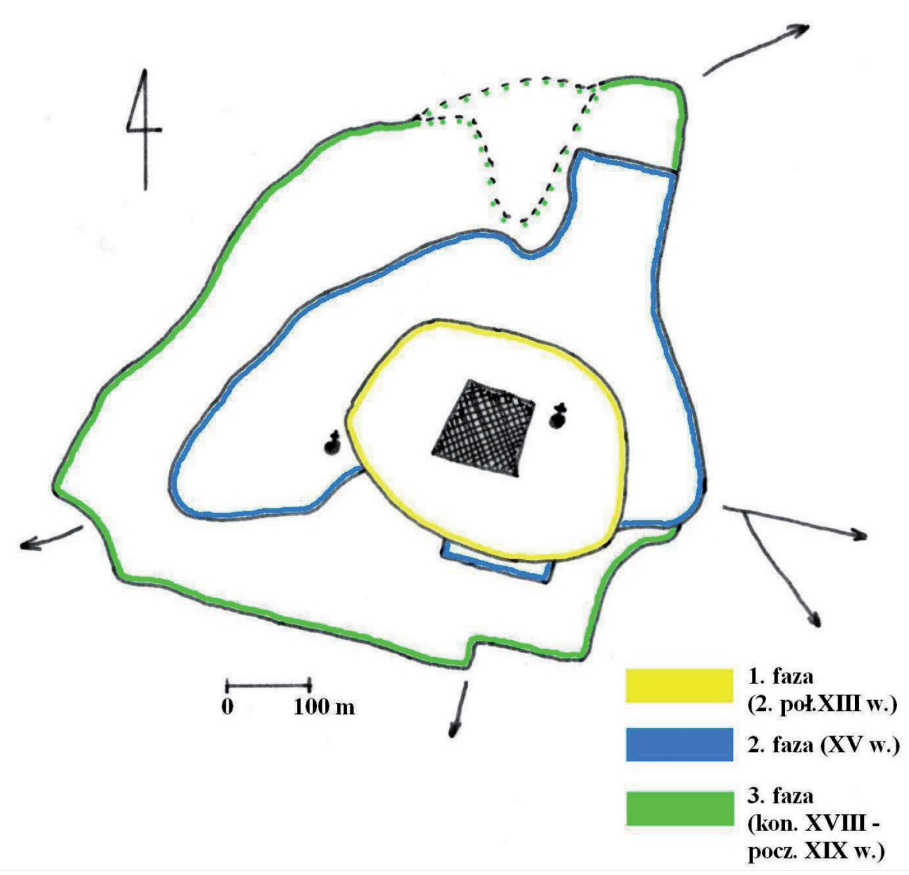

Graph 2. Reconstruction of Pobiedziska demography (the 2nd half of the 13th century till the end of the 18 th c.)

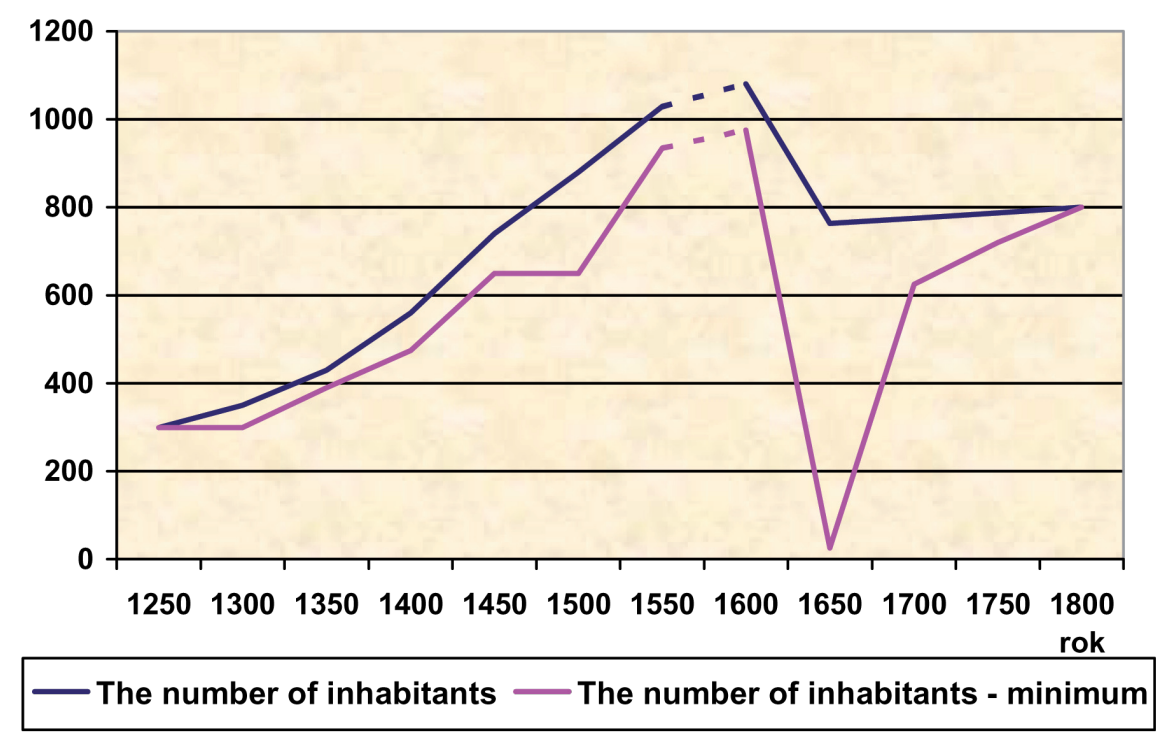


of townsmen linked with the spatial development and the improvement of infrastructure were the elements which changed a town's appearance and character.

\section{THE APPEARANCE OF TOWNS IS CONNECTED WITH USAGE OF THE PLOTS IN THE PAST}

While reconstructing the mean of using the plots in the Medieval Times (Fig. 7$)^{17}$, one can notice that a house stood in front of the plot, whereas behind it two separate or overlapping elements, namely trees, beds with plants or a small field could be found. A tiny plot gave fruit, herbs and vegetables, constituting a supplement of diet. Owing to it some basic needs of the bourgeoisie could be satisfied in their own range. It mostly concerned vegetables and fruit, which he could grow in his own garden behind a house.

Towns had rural and trade character which is seen in medieval usage of plots, for example in Civitates orbis terrarum ${ }^{18}$. This rural character and the medieval usage of plots is also sometimes visible contemporary.

Figure 7. Exemplary usage of the 13th century town plots $(1$ foot $=$ ca $0,313 \mathrm{~m})$
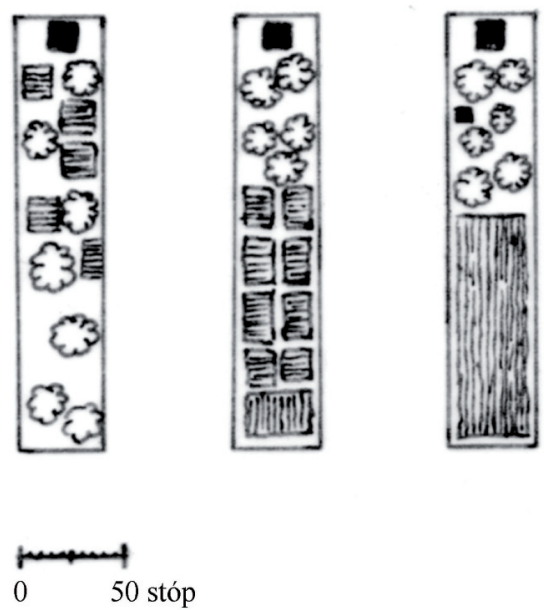

17 M. Kustra, Osadnictwo średniowieczne okolic Pobiedzisk....

18 Civitates orbis terrarum, vol. 1-6, G. Braun, F. Hogenberg (Ed.), Cologne 1572-1617. 
For a very long time, buildings in framework construction was mostly from wood, ca $6 \times 6 \mathrm{~m}$. Later on small houses were built using the halftimbered house building technique, and finally brick tenement houses emerged $^{19}$.

The image of towns is also supplemented by their infrastructure, such as the market and road surfaces.

The market and roads in the oppidum were being improved ${ }^{20}$ :

a) phase 1 - the beginnings of town's existence - the road in the form of a hole, occasionally a clay or wooden surface with a few rocks;

b) phase 2 - a wooden surface more frequent than earlier with clay and stone paving;

c) phase 3 - the end of medieval - huge share of wooden surface and stone paving. It is also possible to encounter various objects or buildings such as mills or stalls.

Further research looks at presenting a more precise picture of the medieval town's infrastructure. The most valuable are here the outcomes of the archaeological research, which need collecting and examining.

\section{SUMMARY}

The research potential concerning towns and cities had a particular aim. I tried to show that various, available pieces of informationm and sources can bring new interesting data connected with the history of towns. It is worth recalling that multi and interdisciplinar studies give a new look into the past.

19 The informtion about the dating at the end of theXIVc. is taken from M.A Wawrzyniak. The data concering the beginning of the 15th c. see: B. Banach, Przemiany zabudowy miasta lokacyjnego w Poznaniu. Od osady Św. Gotarda do miasta z przełomu XV i XVI wieku, [in:] Z. Kurnatowska, T. Jurek (red.), Civitas Posnaniensis. Studia z dziejów średniowiecznego Poznania, Poznań 2005, s. 389-405; P. Wawrzyniak, Rozwój zabudowy mieszkalnej średniowiecznego Poznania (na przykładzie posesji przyrynkowych nr 95-98), w: [in:] Z. Kurnatowska, T. Jurek (red.), Civitas Posnaniensis. Studia z dziejów średniowiecznego Poznania, Poznań 2005, s. 375-388.

20 These changes of surface concerns Pobiedziska, see: M. Kustra, Pobiedziska wraz z okolica w średniowieczu... on the basis of archaeological research of T. Łaszkiewicz and W. Świderski, Pobiedziska, gm. loco, woj. poznańskie - nadzory archeologiczno-konserwatorskie na budowie IV etapu kanalizacji miasta w 1994 i 1995 r., Poznań 1995 and H. Klunder, Nadzór archeologiczny nad budowa kanalizacji w Pobiedziskach (ulice: Kostrzyńska, Powstańców Wielkopolskich), Poznań 2000. 
Historians and archaeologists in their studies are mostly interested in big centers, important events and significant people. We tend to forget about those who were silent participants of past events. Their concerted efforts created reality. That is why I was trying to present the research potential over towns especially those smaller ones. It will be worthwhile to conduct bigger research projects, which will bring into light new crucial issues on medieval Great Poland towns. Using numerous categories of sources could afford reconstruction or construction of towns appearance in the past. Thus, it would be feasible to characterise the spatial development, demography and infrastructure.

Kustra Maurycy - M. A. of archaeology, PhD Candidate at Institute of Prehistory at the Adam Mickiewicz University in Poznan. His scientific interests focus on lay-out and spatial development of medieval towns from Great Poland. He is the author of a book (Pobiedziska wraz z okolica w średniowieczu i u progu nowożytności, 2013), and several articles in scientific journals. 